\title{
Assembly of tomato blistering mosaic virus-like particles using a baculovirus expression vector system
}

\author{
Raquel Medeiros Vasques ${ }^{1,2} \cdot$ Roberto Franco Teixeira Correa $^{2} \cdot$ Leonardo Assis da Silva $^{2} \cdot$ Rosana Blawid $^{3}$. \\ Tatsuya Nagata ${ }^{1} \cdot$ Bergmann Morais Ribeiro $^{2}$ - Daniel M. P. Ardisson-Araújo ${ }^{4}$ (1)
}

Received: 14 November 2018 / Accepted: 27 March 2019 / Published online: 25 April 2019

(c) Springer-Verlag GmbH Austria, part of Springer Nature 2019

\begin{abstract}
The expression of several structural proteins from a wide variety of viruses in heterologous cell culture systems results in the formation of virus-like particles (VLPs). These VLPs structurally resemble the wild-type virus particles and have been used to study viral assembly process and as antigens for diagnosis and/or vaccine development. Tomato blistering mosaic virus (ToBMV) is a tymovirus that has a $6.3-\mathrm{kb}$ positive-sense ssRNA genome. We have employed the baculovirus expression vector system (BEVS) for the production of tymovirus-like particles (tVLPs) in insect cells. Two recombinant baculoviruses containing the ToBMV wild-type coat protein $(\mathrm{CP})$ gene or a modified short amino-terminal deletion $\left(\Delta_{2-24} \mathrm{CP}\right)$ variant were constructed and used to infect insect cells. Both recombinant viruses were able to express ToBMV CP and $\Delta_{2-24} \mathrm{CP}$ from infected insect cells that self-assembled into tVLPs. Therefore, the N-terminal residues (2-24) of the native ToBMV CP were shown not to be essential for self-assembly of tVLPs. We also constructed a third recombinant baculovirus containing a small sequence coding for the major epitope of the chikungunya virus (CHIKV) envelope protein 2 (E2) replacing the native CP $\mathrm{N}$-terminal 2-24 amino acids. This recombinant virus also produced tVLPs. In summary, ToBMV VLPs can be produced in a baculovirus/insect cell heterologous expression system, and the N-terminal residues 2-24 of the CP are not essential for this assembly, allowing its potential use as a protein carrier that facilitates antigen purification and might be used for diagnosis.
\end{abstract}

\section{Introduction}

Tomato blistering mosaic virus (ToBMV) is a member of the genus Tymovirus and the family Tymoviridae and contains a monopartite positive-sense ssRNA genome [1]. ToBMV causes a severe disease worldwide in plants of the genus Solanum, with symptoms that include leaf mosaic and

Handling Editor: Sead Sabanadzovic.

Daniel M. P. Ardisson-Araújo

daniel.araujo@ufsm.br

Raquel Medeiros Vasques

raquel.bonnet@gmail.com

Roberto Franco Teixeira Correa

robertodobrasil@gmail.com

Leonardo Assis da Silva

leocbq@gmail.com

Rosana Blawid

rblawid@gmail.com

Tatsuya Nagata

tatsuya@unb.br blistering [2]. Tymovirus virions are isometric, non-enveloped, and approximately $30 \mathrm{~nm}$ in diameter, arranged in a $\mathrm{T}=3$ icosahedron structure with clustering of coat protein subunits in pentamers and hexamers protruding from the underlying surface [3]. A subgenomic promoter composed of a 16 conserved nucleotides, referred to as the "tymobox", is responsible for the expression of CP [4]. Viral replication takes place in the cytoplasm in association with the double membrane-bounded vesicles that line the periphery

Bergmann Morais Ribeiro bergmann@unb.br

1 Laboratory of Microscopy and Virology, Cell Biology Department, University of Brasilia, Brasília, DF, Brazil

2 Laboratory of Baculovirus, Cell Biology Department, University of Brasilia, Brasília, DF, Brazil

3 Laboratory of Phytovirology, Department of Agronomy, Rural Federal University of Pernambuco, Recife, PE, Brazil

4 Laboratory of Insect Virology, Department of Biochemistry and Molecular Biology, Federal University of Santa Maria, Santa Maria, RS 97105-900, Brazil 
of the chloroplasts and/or mitochondria [3, 5]. Interestingly, previous studies have shown that the $\mathrm{CP}$ of physalis mottle virus (PhyMV) and turnip yellow mosaic virus (TYMV) are able to self-assemble into virus-like particles (VLPs) when expressed in Escherichia coli [6,7].

VLPs can be obtained by the expression of viral structural proteins in several bacterial and eukaryotic heterologous systems [8]. They are almost identical in structure and morphology to virus particles but lack a genome and are therefore noninfectious [9]. VLPs are a highly immunogenic and safe alternative to inactivated infectious viruses. They have already been used as vaccines against several viruses, such as human papilloma virus (HPV) [10], hepatitis B virus (HBV) [11], and influenza A virus [12]. Importantly, the baculovirus expression vector system (BEVS) is a wellestablished eukaryotic-expression-system-based technology that is chosen for the production of a large number of recombinant proteins and is becoming one of the most powerful, robust, and economical systems for protein expression [13]. The BEVS can be used for the production of VLPs, including those from plant viruses [14]. However, despite being a versatile and powerful tool to express different foreign proteins, it is challenging to recover and purify the recombinant protein [15]. To overcome this problem, several strategies focus on tagging the recombinant proteins with carrier proteins or peptides to facilitate protein purification [16].

In this work, we constructed three recombinant baculoviruses to express different variants of the ToBMV CP in insect cells, with the aim of producing ToBMV VLPs (tVLPs). To our knowledge, this is the first study that evaluates tymovirus-like particle assembly using a BEVS and its potential as a carrier structure for short epitopes to facilitate production and purification.

\section{Materials and methods}

\section{Construction of recombinant bacmids containing the ToBMV $c p$ gene and its variants}

Three different $\mathrm{CP}$ variants were generated to construct the recombinant baculoviruses: (i) the complete $c p$ of ToBMV (CP variant); (ii) a mutant of the ToBMV cp (23-amino-acid deletion in the amino-terminal region of the predicted CP protein) $\left(\Delta_{2-24} \mathrm{CP}\right.$ variant); and (iii) a mutant fusion with the E2 epitope of chikungunya virus (CHIKV) (QRRSTKDNFNVYKATRPYLAHCPDC; E2- $\Delta$ CP variant). As a DNA template for the PCR reaction, we used a previously constructed cDNA clone, pToBMV (accession number KT834406) [17]. For CP amplification, we used the primers ToBMV-CP-F (5'-AAG CTT GAA TTC ATG GAT CCC AGT ACT TCA AAC ACC ATC-3') and ToBMV-CP-R (5'CCA TGG CTG CAG CTA GGA GGA TTG AAG AAG
AGG AGA GGA-3'). For $\Delta_{2-24} \mathrm{CP}$, we used ToBMV-CPDel-F (5'-AAG CTT GAA TTC ATG ACC CCC ACC ACT GAA CTC TCC GGA GC-3') together with ToBMV-CP-R. For E2- $\Delta_{2-24} \mathrm{CP}$ amplification, we performed a two-step PCR for subsequent addition of the E2-epitope-encoding nucleotide sequence to the $\Delta_{2-24} \mathrm{CP}$ variant. In the first step, we used the primer F2 (5'-TTT ACA AGG CCA CTA GAC CAT ACT TGG CCC ACT GCC CAG ATT GTA CCC CCA CCA CTG AAC TCT CCG GAG CCA TTG-3') together with ToBMV-CP-R and, as a template, pToBMV. F2 binds to the $\Delta_{2-24} \mathrm{CP}$ variant of the $\mathrm{CP}$ gene and inserts a partial E2 epitope sequence. The resulting fragment was used as a template in a second reaction with the primer F2 ( $5^{\prime}$-AAG CTT GAA TTC ATG CAA CGT CGT TCA ACA AAA GAC AAT TTT AAT GTT TAC AAG GCC ACT AGA CCA TAC TTG GCC-3') together with ToBMV-CP-R. The purified fragments were individually digested with $E c o$ RI/PstI and separately cloned into pFastBac ${ }^{\mathrm{TM}} 1$ (Invitrogen, Carlsbad, CA, USA) digested with the same enzymes to generate three transfer vectors. The transfer vectors were individually transferred into DH10-Bac cells (Invitrogen, Carlsbad, CA, USA) by heat shock. Recombinant bacmids were selected and confirmed by PCR following the manufacturer's instructions (Bac-to-Bac ${ }^{\circledR}$, Baculovirus Expression Systems, Invitrogen, Carlsbad, CA, USA). One $\mu \mathrm{g}$ of each recombinant bacmid was induced by transfection into Trichoplusia $n i$ (BTI-Tn5B1-4, herein called Tn5B) cells $\left(10^{6}\right)$ [18] using liposomes (Cellfectin ${ }^{\circledR}$ ) according to the manufacturer's instructions (Invitrogen, Carlsbad, CA, USA). Tn5B cells were cultured at $27^{\circ} \mathrm{C}$ in TC-100 medium (Vitrocell, Campinas, SP, Brazil) supplemented with $10 \%$ fetal bovine serum (Thermo Fisher, Walthan, MA, USA). The supernatant of cells containing the recombinant viruses vAc-ToBMV-CP, vAc-ToBMV- $\Delta_{2-24} \mathrm{CP}$ and vAc-ToBMV-E2- $\Delta_{2-24} \mathrm{CP}$ were collected at seven days post-transfection, amplified in Tn5B cells, and titered as previously described elsewhere [19].

\section{Protein expression analysis in Tn5B cells}

For the infection of Tn5B cells with baculovirus, the viral stock was added to the cells $\left(1-2 \times 10^{6}\right.$ cells $\left./ \mathrm{mL}\right)$ at a multiplicity of infection (MOI) of 5. At four days postinfection (d.p.i.), the infected cells and the culture supernatant were separated by centrifugation at $5,000 \times g$ for $5 \mathrm{~min}$. The cells were washed with phosphate-buffered saline (PBS, $3 \mathrm{~mL} ; 137 \mathrm{mM} \mathrm{NaCl}, 2.7 \mathrm{mM} \mathrm{KCl}, 10 \mathrm{mM} \mathrm{Na}_{2} \mathrm{HPO}_{4}, 2 \mathrm{mM}$ $\left.\mathrm{KH}_{2} \mathrm{PO}_{4} ; \mathrm{pH} 7.4\right)$ and pelleted by centrifugation at 5,000 $\times g$ for $5 \mathrm{~min}$. Western and dot blot analyses were used to evaluate the specificity of ToBMV CP variants using a ToBMV $\mathrm{CP}$-specific polyclonal antibody (kindly provided by Alice K. Inoue-Nagata, Embrapa Hortaliças, Brasília, Brazil). For Western blot, the pellet was resuspended in PBS, and the total protein was quantified by the Bradford method 
(Bio-Rad, Hercules, CA, USA) according to the manufacture's protocol. Cell extract samples were mixed with equal volumes of $2 \mathrm{x}$ protein loading buffer $(0.25 \mathrm{M}$ Tris- $\mathrm{Cl}, \mathrm{pH}$ $6.8,4 \%$ SDS, $20 \%$ glycerol, $10 \%$ 2-mercaptoethanol, and $0.02 \%$ bromophenol blue) and incubated at $100{ }^{\circ} \mathrm{C}$ for $5 \mathrm{~min}$. Samples were resolved by $12 \%$ SDS-PAGE [20], transferred onto a polyvinylidene fluoride (PVDF) membrane (Millipore, Burlington, MA, USA), and probed with a rabbit antiToBMV-CP polyclonal antibody. The probing was followed by incubation with alkaline-phosphatase-conjugated antirabbit secondary antibody (Sigma-Aldrich, St. Louis, MO, USA). Blots were developed using alkaline phosphatase buffer (100 mM Tris-HCl, $100 \mathrm{mM} \mathrm{NaCl,} 5 \mathrm{mM} \mathrm{MgCl}$; $\mathrm{pH}$ 9.5) containing $3.5 \mathrm{mM}$ 5-bromo-4-chloro-3-indolyl phosphate (BCIP) (Sigma-Aldrich, St. Louis, MO, USA) and 3.7 $\mathrm{mM}$ nitro blue tetrazolium (NBT) (Sigma-Aldrich, St. Louis, MO, USA). Leaf extracts of ToBMV-infected symptomatic Nicotiana benthamiana were used as positive control, while control virus vAc-occ- (occlusion-negative Autographa californica multiple nucleopolyhedrovirus) [16] and uninfected Tn5B cells were used as a negative control. For dot blot analysis, the crude cell extracts, lysate and purified proteins were manually dotted on a nitrocellulose membrane and probed using the same procedure as above.

\section{Light and immunofluorescence microscopy}

In order to examine the cytolocalization of the expressed $\mathrm{CP}$ variants in insect cells during baculovirus infection, we performed an immunofluorescence (IF) assay using infected Tn5B cells and anti-ToBMV-CP antibody. Monolayers of Tn5B $\left(5.0 \times 10^{6}\right)$ cells were infected at an MOI of 5 with recombinant vAc-ToBMV-CP, vAc-ToBMV- $\Delta_{2-24} \mathrm{CP}$, or vAc-ToBMV-E2- $\Delta_{2-24} \mathrm{CP}$, and after $72 \mathrm{~h}$ p.i., the cells were fixed with $3.7 \%$ formalin and incubated for $1 \mathrm{~h}$ with a 1:200 dilution of polyclonal rabbit anti-ToBMV-CP in PBS. After the washing, the cells were incubated with fluorescent Alexa Fluor 488 anti-rabbit IgG secondary antibody (Thermo Fisher, Walthan, MA, USA). Images were taken with a Zeiss Apotome Axiovert 200 (Zeiss, Munich, Germany) and processed with AxioVision 4.8.

\section{Purification, negative staining, and transmission electron microscopy of tVLPs}

Infected cells were harvested from an $80 \%$ confluent 72 -h-old culture in a T75 culture flask and centrifuged at $5,000 \times g$ for $5 \mathrm{~min}$. The resulting pellets containing the infected cells were washed twice with PBS, followed each time by centrifugation at $5,000 \times g$ for $5 \mathrm{~min}$. The cells were then resuspended in $500 \mu \mathrm{L}$ of PBS and lysed by sonication on ice for $15 \mathrm{~s}$ (Sonics Vibracell, output $2 \mathrm{~W}$ ). The lysate was clarified by centrifugation at $5,000 \times g$ for $5 \mathrm{~min}$., and the supernatant was subjected to ultracentrifugation for $3 \mathrm{~h}$ at $100,000 \times g$ onto a sucrose cushion $(25 \%$ sucrose in PBS). The pellets were resuspended in $500 \mu \mathrm{L}$ of PBS, and a small drop of each sample was spotted onto a carbon-coated copper grid and negatively stained with $2 \%$ (w/v) uranyl acetate. The grids were examined using a transmission electron microscope (JEOL JEM 1011, JEOL, MA, USA).

\section{Results}

\section{Virus construction and protein expression}

Two transfer vectors containing the $c p$ variants were used to construct the recombinant baculoviruses vAc-ToBMV-CP and vAc-ToBMV- $\Delta_{2-24} \mathrm{CP}$. We observed baculovirus cytopathic effects when Tn5B cells were infected with either vAc-ToBMV-CP or vAc-ToBMV- $\Delta_{2-24}$-CP that were similar to those observed with the control virus, vAc/ooc-. The cytopathic effects included hypertrophy of the nucleus and cell rounding (Fig. 1A). The infected cells were harvested and tested for protein expression by immunoblot analysis (Fig. 1B). The proteins were detected using an anti-ToBMV$\mathrm{CP}$ antibody (anti-CP). The predicted molecular mass of the CP protein $(19.8 \mathrm{kDa})$ and $\Delta_{2-24} \mathrm{CP}(17.4 \mathrm{kDa})$ corresponded to the immunoreactive band observed in the immunoblot. No bands were detected in uninfected or vAc/oocinfected cell extracts.

\section{Immunofluorescence analysis of infected cells}

Uninfected Tn5B cells exhibited very low background fluorescence, while infected cells expressing the $\mathrm{CP}$ variants were labeled (Fig. 2). IF analysis showed that both $\mathrm{CP}$ and $\Delta_{2-24} \mathrm{CP}$ variants accumulated in the cytosol during virus infection.

\section{Tymovirus-like particle (tVLP) formation during baculovirus infection}

We used dot blot analysis to probe both the crude extract and the pellet obtained by ultracentrifugation with a ToBMV-CP antibody (Fig. 3A). Reactive dots were found in crude extract and purified putative tVLPs from the two variants. We found no signals with the extract from uninfected cells. For analysis of tVLP assembly, we performed negative staining [21] on the pellet material and examined the putative VLPs using transmission electron microscopy (Fig. 3B, black arrowhead). The sizes of the VLPs were not regular and varied from 10 to $50 \mathrm{~nm}$. Both variants, CP and $\Delta_{2-24}-\mathrm{CP}$, formed icosahedral virus-like particles that resembled tymovirus capsids (the native virus is not shown), confirming that the recombinant proteins expressed in 
A

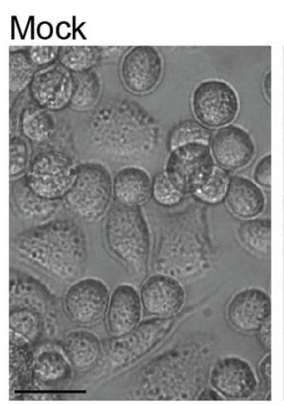

vAc/occ-

$\mathrm{CP}$

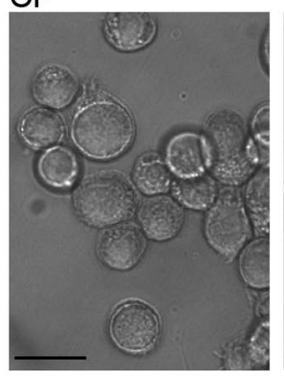

$\triangle 2-24-C P$

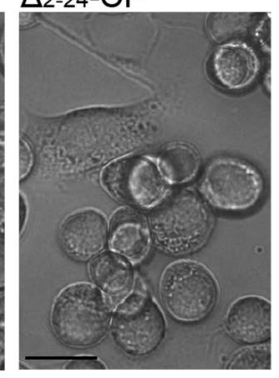

B

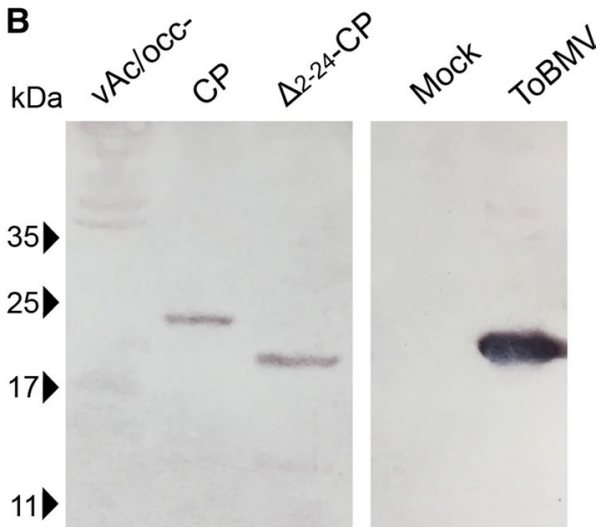

Fig. 1 Expression of recombinant tomato blistering mosaic virus (ToBMV) coat protein (CP) analyses. (A) Uninfected Tn5B cells and Tn5B cells infected for $72 \mathrm{~h}$ with vAc/occ-, vAc-ToBMV-CP, or vAc-ToBMV- $\Delta_{2-24}-\mathrm{CP}$. The infected cells display hypertrophy of the nucleus, cell rounding, and loss of the fusiform shape observed in uninfected cells. Scale bar $=50 \mu \mathrm{m}$. (B) Western blot showing the presence of specific bands corresponding to the recombinant $\mathrm{CP}$ variants expressed during virus infection

baculovirus were capable of assembling into VLPs (Fig. 3B, black arrowhead). Negative staining revealed rod-shaped baculovirus capsids (Fig. 3B, CP field, white arrowhead).

\section{ToBMV cp carrying the CHIKV epitope}

To determine whether tVLPs are capable of carrying small peptides, we evaluated the assembly of tVLPs containing an immunogenic E2 epitope of CHIKV fused to the $\Delta_{2-24}$ CP variant of the ToBMV CP. The transfer vector sequence was confirmed by DNA sequencing and used to construct a recombinant baculovirus, vAc-ToBMV-E2- $\Delta_{2-24}$ CP. Typical cytopathic effects of baculovirus infection were also observed in Tn5B cells after infection (Fig. 4A). The recombinant protein $\mathrm{E} 2-\Delta_{2-24}-\mathrm{CP}$ was detected using an antiToBMV-CP antibody (anti-CP) (Fig. 4B). The predicted molecular mass of the E2- $\Delta_{2-24}$-CP with an additional 25 amino acid residues at its $\mathrm{N}$-terminus $(20.3 \mathrm{kDa})$ is similar to that of the immunoreactive band observed in the Western blots (Fig. 4B). No band was detected in either vAc/occ- and uninfected cell extracts (not shown). We also performed an IF analysis of vAc-ToBMV-E2- $\Delta_{2-24}$-CP-infected Tn5B cells at $72 \mathrm{~h}$ p.i. We found that the E2- $\Delta_{2-24}-\mathrm{CP}$ protein of ToBMV accumulated in the cytosol of Tn5B cells, as observed for $\mathrm{CP}$ and $\Delta_{2-24}$-CP (Fig. 4C). The results of dot blot analysis showed that the ToBMV CP antibody reacted strongly with crude lysates, and purified extracts of cells infected with vAc-ToBMV-E2- $\Delta_{2-24}$-CP after ultracentrifugation of the infected cell lysate onto a sucrose cushion (Fig. 4D). Importantly, TEM examination of purified extracts of Tn5B cells infected with vAc-ToBMV-E2- $\Delta_{2-24}$-CP revealed icosahedral virus-like particles resembling typical tymovirus virions, showing that the recombinant protein $\mathrm{E} 2-\Delta_{2-24}-\mathrm{CP}$ carrying a heterologous small peptide sequence was able of self-assembly into a VLP (Fig. 4E).

\section{Discussion and conclusions}

The last two decades have witnessed the growing use of the eukaryotic baculovirus expression system to produce a great number of recombinant proteins [22]. In this study, we expressed the ToBMV coat protein (CP) using this system for the production of tymovirus-like particles (tVLPs). The expression system enabled the formation of tVLPs from two different $\mathrm{CP}$ variants: a full-length variant $(\mathrm{CP})$ and an amino-terminal deletion mutant lacking 23 amino acids $\left(\Delta_{2-24}-\mathrm{CP}\right)$ of the native CP. We also found that the fusion of a small peptide based on the envelope protein E2 of the CHIKV did not change the self-assembly properties of a deletion mutant of ToBMV CP.

The use of plant virus-like particles as carrier proteins is a very promising approach for displaying epitopes and facilitating their purification, taking advantage of the high density of the particles [23]. Members of different families of plant viruses have been used to produce VLPs using the baculovirus expression vector system (BEVS), including arabis mosaic virus [24], tobacco ringspot virus [25], cowpea mosaic virus (CPMV) [26], beet western yellows virus [27], potato leaf roll virus [14, 28], pea enation mosaic virus [29], and rice dwarf virus [30]. None of those viruses are members of the genus Tymovirus or were used as a carrier structure to carry epitopes. The expression of tobacco ringspot virus (TRSV) coat protein in insect cells using a BEVS enabled the formation of empty VLPs that were similar in 
Fig. 2 Immunofluorescence analysis of Tn5B cells infected with recombinant baculoviruses expressing tomato blistering mosaic virus coat protein (ToBMV CP) variants. The figure shows Tn5B cells infected with either $\mathrm{VAc}-\mathrm{ToBMV}-\mathrm{CP}$ or vAc-ToBMV- $\Delta_{2-24}-\mathrm{CP}$ at $72 \mathrm{~h}$ p.i. and incubated with rabbit polyclonal antibodies raised against the ToBMV CP protein, after DAPI staining to show nuclear localization

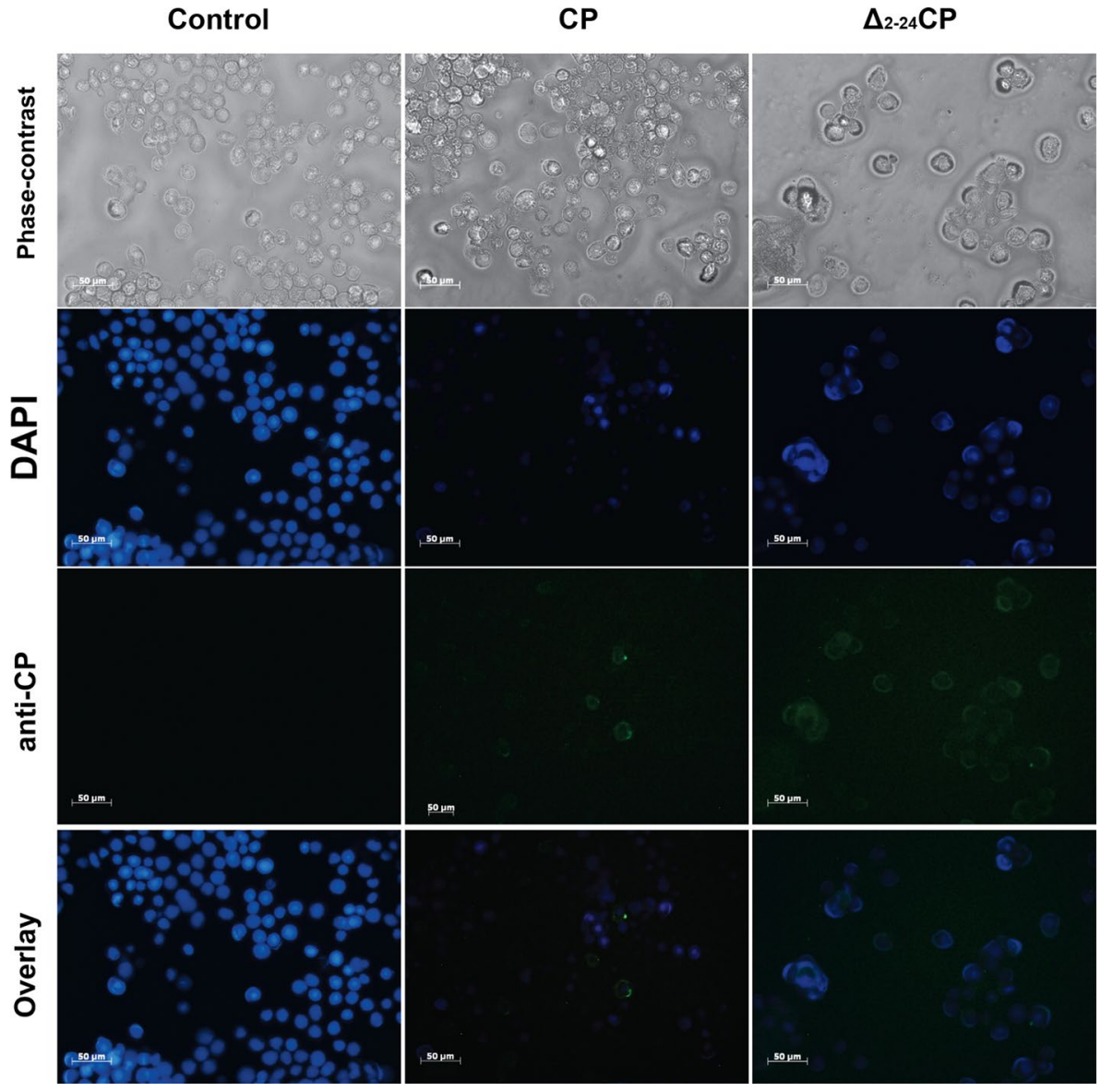

B

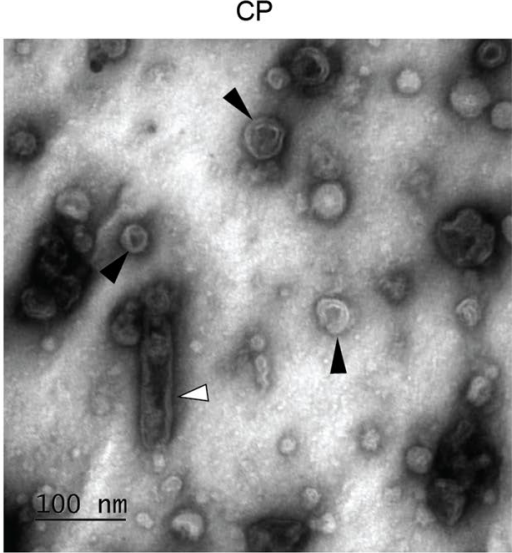

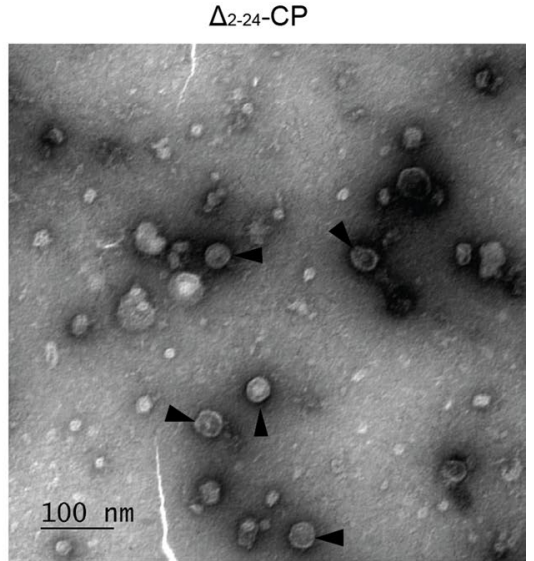

Fig. 3 (A) Dot blot analysis of the crude lysates and purified extracts from infected cells using vAc-ToBMV-CP or vAc-ToBMV- $\Delta 2-24-C P$ recombinant viruses and anti-ToBMV-CP antibody. Visible positive signals are present in the lanes containing $\mathrm{CP}$, but not in the vAc-occ(negative control) lane, for the total extract, the lysate, and the puri-

structure to the native virus particles [25]. Interestingly, in the case of CPMV, two coat proteins were expressed either individually or together in insect cells using a BEVS. Only co-expression from separate promoters in the same fied particles. (B) Electron micrographs of virus-like particles (VLPs) assembled during vAc-ToBMV-CP or vAc-ToBMV- $\Delta_{2-24}$ CP infection. The tVLPs are indicated by a black arrowhead. White arrowheads indicate rod-shaped baculovirus nucleocapsids. Bars in panels $\mathbf{B}$ and $\mathbf{C}, 100 \mathrm{~nm}$

construct resulted in the formation of VLPs whose morphology closely resembled that of native CPMV virions [26]. Furthermore, the coat protein of beet western yellows virus (BWYV) was expressed using recombinant Bombyx mori 
A

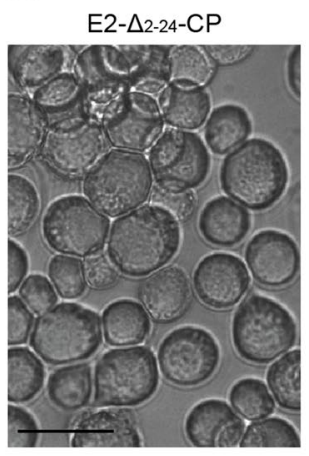

B

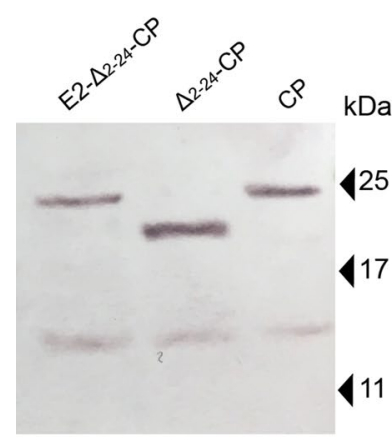

C

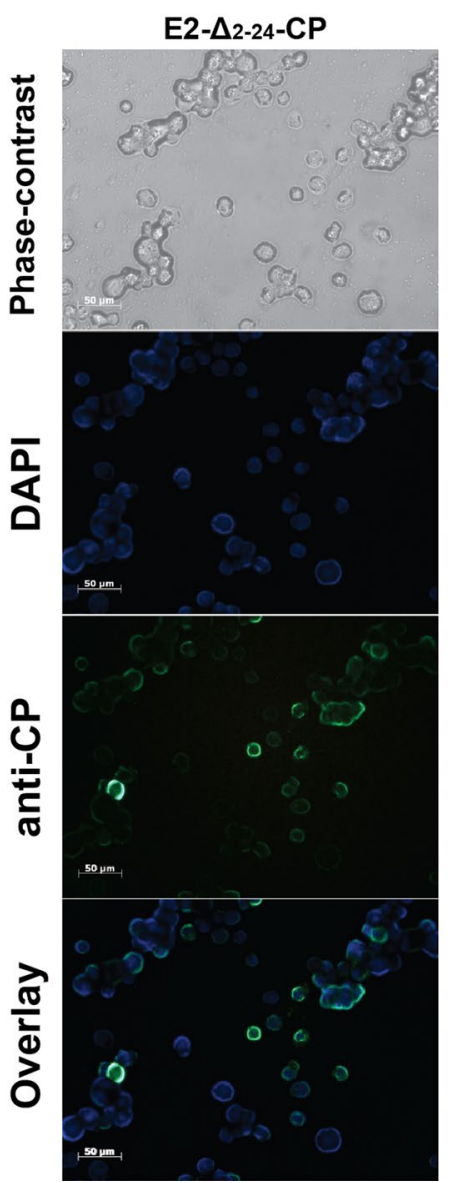

D

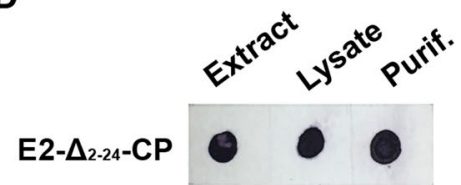

E
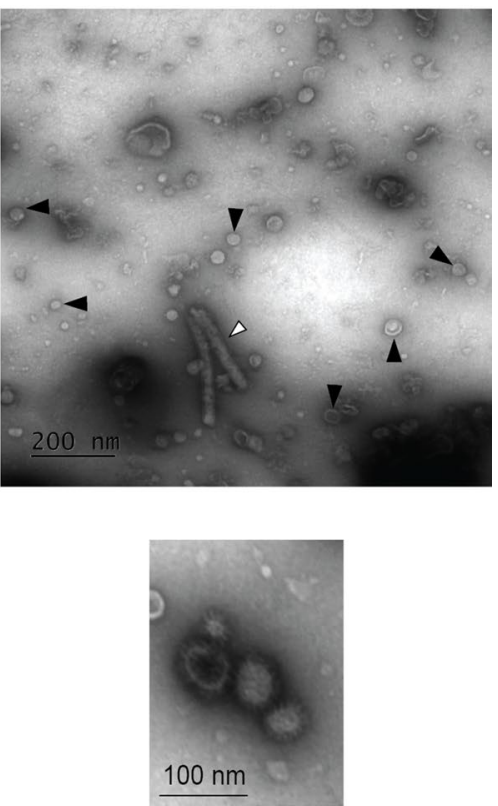

Fig. 4 Analysis of recombinant E2- $\Delta_{2-24}$ CP protein expression. (A) Cytopathic effects induced by the infection of recombinant Tn5B cells with E2- $\Delta_{2-24}$ CP. (B) Western blot showing the presence of specific bands corresponding to $\mathrm{CP}$ variants expressed during recombinant baculovirus infection. (C) Immunofluorescence analysis of Tn5B cells infected with vAc-ToBMV-E2- $\Delta_{2-24}-\mathrm{CP}$ baculovirus. The figure shows $\mathrm{Tn} 5 \mathrm{~B}$ cells infected at $72 \mathrm{~h}$ p.i. and incubated with rabbit polyclonal antibodies raised against the ToBMV CP protein and DAPI staining to show nuclear localization. (D) Dot blot analy- sis of crude lysates and purified extracts from infected cells, using vAc-ToBMV-E2- $\Delta_{2-24}$-CP recombinant virus and anti-ToBMV-CP antibody. Visible positive signals are present in the three dots. The negative control is not shown, as it did not generate any signal. (E) Electron micrographs of virus-like particles (VLPs) assembled from vAc-ToBMV-E2- $\Delta_{2-24}$-CP infection. The tVLPs are indicated by a black arrowhead, which is highlighted in the additional box below. White arrowheads indicate rod-shaped baculovirus nucleocapsids

a very similar structure to those found in this work [34]. The tVLPs expressed in BEVS varied in size from 10 to $30 \mathrm{~nm}$. When the pea enation mosaic virus (PEMV) CP was expressed in insect cells from a recombinant baculovirus, VLPs were produced that varied in size from 13 to $30 \mathrm{~nm}$.

The BEVS is highly versatile platform for the production of structurally and immunologically functional VLPs [22] and protein display. There are many strategies using the budded virus as a fusion partner or for surface presentation of target proteins in insect cells (the major envelope protein and the capsid protein). Furthermore, other viral proteins can be used as well, for example, the vesicular stomatitis virus $\mathrm{G}$ protein or the influenza hemagglutinin [35]. The BEVS can yield protein at levels comparable to those achieved in 
bacteria or yeast, but its ability to perform complex posttranslational modifications (e.g. glycosylation) is greater, and thus it is a better system for producing complex VLPs [23]. The major limitation of using an insect cell system is the purification step, due to the coproduction of baculovirus particles, a contaminant that must be biophysically or biochemically separated from VLPs (e.g., using cesium chloride ultracentrifugation or ion exchange chromatography), as they can significantly impact production efficiency [8]. This issue can be easily overcome by blocking the formation of baculovirus particles, as has been shown previously in a study of HIV VLP production and purification [36].

In conclusion, the expression of ToBMV $\mathrm{CP}$ gene in BEVS enables VLP self-assembly in insect cells. The N-terminal residues 2-24 of the native ToBMV CP are not essential for self-assembly into VLPs in the BEVS and can be replaced by a different sequence with medical significance, such as an epitope from a human pathogen. The modified tymovirus CP could be used as a protein carrier without affecting the self-assembly properties of the $\mathrm{CP}$ and, as a consequence, epitope purification and display. Therefore, tVLPs carrying small peptides facilitate antigen purification and display for vaccine production and/or other purposes.

Funding This work was supported by Fundação de Apoio à Pesquisa do Distrito Federal (FAPDF, Grant number 193.001532/2016). Conselho Nacional de Desenvolvimento Científico e Tecnológico (Grant number 428799/2018-3). Coordenação de Aperfeiçoamento de Pessoal de Nível Superior (Grant number CAPES/PROEX 23038.005848/2018-31).

\section{Compliance with ethical standards}

Conflict of interest The authors declare that they have no competing interests.

\section{References}

1. Martelli GP, Sabanadzovic S, Abou-Ghanem Sabanadzovic N, Edwards MC, Dreher T (2002) The family Tymoviridae. Arch Virol 147:1837-1846. https://doi.org/10.1007/s007050200045

2. Blawid R, Hayashi EAI, Rezende JA, Kitajima EW, Nagata T (2016) A highly divergent isolate of tomato blistering mosaic virus from Solanum violaefolium. Virus Genes 52:294-298. https ://doi.org/10.1007/s11262-016-1288-Z

3. Canady MA, Larson SB, Day J, McPherson A (1996) Crystal structure of turnip yellow mosaic virus. Nat Struct Biol 3:771781. https://doi.org/10.1038/nsb0996-771

4. Ding SW, Howe J, Keese P et al (1990) The tymobox, a sequence shared by most tymoviruses: its use in molecular studies of tymoviruses. Nucleic Acids Res 18:1181-1187. https://doi.org/10.1093/ nar/18.5.1181

5. Tanaka FAO, Machado SR, Barradas MM (2000) Análise ultraestrutural de folhas de três espécies de Solanaceae após inoculação com o vírus da necrose branca do tomateiro (VNBT-Tymovirus). Braz J Bot 23:161-167. https://doi.org/10.1590/S0100-84042 000000200006
6. Powell JD, Barbar E, Dreher TW (2012) Turnip yellow mosaic virus forms infectious particles without the native beta-annulus structure and flexible coat protein $\mathrm{N}$-terminus. Virology 422:165-173. https://doi.org/10.1016/j.virol.2011.10.019

7. Sastri M, Kekuda R, Gopinath K, Kumar CT, Jagath JR, Savithri HS (1997) Assembly of physalis mottle virus capsid protein in Escherichia coli and the role of amino and carboxy termini in the formation of the icosahedral particles. J Mol Biol 272:541552. https://doi.org/10.1006/jmbi.1997.1258

8. Liu F, Wu X, Li L, Liu Z, Wang Z (2013) Use of baculovirus expression system for generation of virus-like particles: successes and challenges. Protein Expr Purif 90:104-116. https:// doi.org/10.1016/j.pep.2013.05.009

9. Noad R, Roy P (2003) Virus-like particles as immunogens. Trends Microbiol 11:438-444. https://doi.org/10.1016/S0966 $-842 \mathrm{X}(03) 00208-7$

10. Harper DM (2009) Currently approved prophylactic HPV vaccines. Expert Rev Vaccines 8:1663-1679. https://doi. org/10.1586/erv.09.123

11. Fagan EA, Tolley P, Smith HM et al (1987) Hepatitis B vaccine: immunogenicity and follow-up including two year booster doses in high-risk health care personnel in a London teaching hospital. J Med Virol 21:49-56. https://doi.org/10.1002/jmv.1890210107

12. Cox MM, Hashimoto $Y$ (2011) A fast track influenza virus vaccine produced in insect cells. J Invertebr Pathol 107(Suppl):S31-S41. https://doi.org/10.1016/j.jip.2011.05.003

13. Felberbaum RS (2015) The baculovirus expression vector system: a commercial manufacturing platform for viral vaccines and gene therapy vectors. Biotechnol J 10:702-714. https://doi. org/10.1002/biot.201400438

14. Lamb JW, Duncan GH, Reavy B, Gildow FE, Mayo MA, Hay RT (1996) Assembly of virus-like particles in insect cells infected with a baculovirus containing a modified coat protein gene of potato leafroll luteovirus. J Gen Virol 77:1349-1358. https://doi.org/10.1099/0022-1317-77-7-1349

15. Fuenmayor J, Gòdia F, Cervera L (2017) Production of viruslike particles for vaccines. New Biotechnol 39:174-180. https ://doi.org/10.1016/j.nbt.2017.07.010

16. Ardisson-Araújo DMP, Morgado FDS, Schwartz EF, Corzo G, Ribeiro BM (2013) A new theraphosid spider toxin causes early insect cell death by necrosis when expressed in vitro during recombinant baculovirus infection. PLoS One 8:e84404. https ://doi.org/10.1371/journal.pone.0084404

17. Blawid R, Nagata $\mathrm{T}$ (2015) Construction of an infectious clone of a plant RNA virus in a binary vector using one-step Gibson Assembly. J Virol Methods 222:11-15. https://doi. org/10.1016/j.jviromet.2015.05.003

18. Granados RR, Guoxun L, Derksen ACG, McKenna KA (1994) A new insect cell line from Trichoplusia ni (BTI-Tn-5B1-4) susceptible to Trichoplusia ni single enveloped nuclear polyhedrosis virus. J Invertebr Pathol 64:260-266. https://doi. org/10.1016/S0022-2011(94)90400-6

19. O'Reilly DR, Miller LK, Luckow VA (1992) Baculovirus expression vectors. A laboratory manual. Freeman and Company, New York. https://doi.org/10.1016/0092-8674(93)90288 $-2$

20. Sambrook J, Russel D (2001) Molecular cloning: a laboratory manual, 3rd edn. Cold Spring Harbor Laboratory Press, New York

21. Brenner S, Horne RW (1959) A negative staining method for high resolution electron microscopy of viruses. Biochim Biophys Acta 34:103-110. https://doi.org/10.1016/0006-3002(59)90237-9

22. van Oers MM, Pijlman GP, Vlak JM (2015) Thirty years of baculovirus-insect cell protein expression: from dark horse to mainstream technology. J Gen Virol 96:6-23. https://doi.org/10.1099/ vir.0.067108-0 
23. Roldão A, Mellado MCM, Castilho LR, Carrondo MJ, Alves PM (2010) Virus-like particles in vaccine development. Expert Rev Vaccines 9:1149-1176. https://doi.org/10.1586/erv.10.115

24. Bertioli DJ, Harris RD, Edwards ML, Cooper JI, Hawes WS (1991) Transgenic plants and insect cells expressing the coat protein of arabis mosaic virus produce empty virus-like particles. J Gen Virol 72:1801-1809. https://doi. org/10.1099/0022-1317-72-8-1801

25. Singh S, Rothnagel R, Prasad BVV, Buckley B (1995) Expression of tobacco ringspot virus capsid protein and satellite RNA in insect cells and three-dimensional structure of tobacco ringspot virus-like particles. Virology 213:472-481. https://doi. org/10.1006/viro.1995.0020

26. Shanks M, Lomonossoff GP (2000) Co-expression of the capsid proteins of cowpea mosaic virus in insect cells leads to the formation of virus-like particles. J Gen Virol 81:3093-3097. https://doi. org/10.1099/0022-1317-81-12-3093

27. Tian T, Medina V, Mayhew DE, Maeda S, Falk BW (1995) Beet western yellows luteovirus capsid proteins produced by recombinant baculoviruses assemble into virion-like particles in cells and larvae of Bombyx mori. Virology 213:204-212. https://doi. org/10.1006/viro.1995.1560

28. Gildow FE, Reavy B, Mayo MA et al (2000) Aphid acquisition and cellular transport of potato leafroll virus-like particles lacking P5 readthrough protein. Phytopathology 90:1153-1161. https:// doi.org/10.1094/PHYTO.2000.90.10.1153

29. Sivakumar S, Wang Z, Harrison RL, Liu S, Miller WA, Bonning BC (2009) Baculovirus-expressed virus-like particles of pea enation mosaic virus vary in size and encapsidate baculovirus mRNAs. Virus Res 139:54-63. https://doi.org/10.1016/j.virus res.2008.10.002

30. Hagiwara K, Higashi T, Namba K, Uehara-Ichiki T, Omura T (2003) Assembly of single-shelled cores and double-shelled virus-like particles after baculovirus expression of major structural proteins P3, P7 and P8 of rice dwarf virus. J Gen Virol 84:981-984. https://doi.org/10.1099/vir.0.18904-0

31. Sastri M, Reddy DS, Krishna SS, Murthy MR, Savithri HS (1999) Identification of a discrete intermediate in the assembly/disassembly of physalis mottle tymovirus through mutational analysis. J Mol Biol 289:905-918. https://doi.org/10.1006/jmbi.1999.2786

32. Shahana PV, Das D, Gontu A, Chandran D, Maithal K (2015) Efficient production of Tymovirus like particles displaying immunodominant epitopes of Japanese Encephalitis Virus envelope protein. Protein Expr Purif 113:35-43. https://doi.org/10.1016/j. pep.2015.03.017

33. Shin H-I, Chae K-H, Cho T-J (2013) Modification of turnip yellow mosaic virus coat protein and its effect on virion assembly. BMB Rep 46:495-500. https://doi.org/10.5483/BMBRE P.2013.46.10.046

34. Hayden CM, Mackenzie AM, Skotnicki ML, Gibbs A (1998) Turnip yellow mosaic virus isolates with experimentally produced recombinant virion proteins. J Gen Virol 79:395-403. https://doi. org/10.1099/0022-1317-79-2-395

35. Grabherr R, Ernst W (2010) Baculovirus for eukaryotic protein display. Curr Gene Ther 10:195-200. https://doi. org/10.2174/156652310791321297

36. Chaves LCS, Ribeiro BM, Blissard GW (2018) Production of GP64-free virus-like particles from baculovirus-infected insect cells. J Gen Virol 99:265-274. https://doi.org/10.1099/jgv.0.00100 2

Publisher's Note Springer Nature remains neutral with regard to jurisdictional claims in published maps and institutional affiliations. 